\title{
Alternative biomarkers for assessing glycemic control in diabetes: fructosamine, glycated albumin, and 1,5-anhydroglucitol
}

Ji-Eun Lee, MD, PhD

Departments of Pediatrics, Inha University Hospital, Inha University Graduate School of Medicine, Incheon, Korea
Received: 26 June, 2015

Accepted: 26 June, 2015

Address for correspondence: Ji-Eun Lee, MD, PhD

Department of Pediatrics, Inha University Hospital, Inha University Graduate School of medicine, 27 Inhang-ro, Jung-gu, Incheon 400711 , Korea

Tel: $+82-32-890-3617$

Fax: +82-32-890-3099

E-mail: anicca@inha.ac.kr
The growing attention to alternative glycemic biomarkers including fructosamine, glycated albumin (GA), 1,5-anhydroglucitol (1,5-AG), is attributable to the limitations of the glycated hemoglobin ( $\mathrm{HbA1c}$ ) assay. It is important to recognize the conditions in which $\mathrm{HbA} 1 \mathrm{c}$ levels may be difficult to interpret. Serum fructosamine and GA have been proposed useful tools for monitoring of short-term glycemic control. These biomarkers not only reflect well glycemic control in hematologic disorder, but also represent postprandial glucose fluctuation. Serum 1,5-AG may be useful for estimating within-day glucose variation. Use of these nontraditional tests can be more helpful in the management of diabetes as complement traditional measures. Further larger cohort studies are warranted to determine whether nontraditional biomarkers have potential utility for early diagnosis, management of diabetes, and prevention of diabetic complications.

Keywords: Diabetes mellitus, Fructosamine, Glycosylated serum albumin, 1,5-anhydroglucitol, Biological markers

\section{Introduction}

Diabetes mellitus (DM) is a chronic metabolic syndrome exhibiting hyperglycemia. Strict glycemic control is essential for preventing the complications of diabetes. Serum glycemic biomarkers have been effective measures used to monitor glycemic control in clinical practice ${ }^{1)}$. Traditionally, glycated hemoglobin ( $\mathrm{HbAlc}$ ) has been used as the standard measure for long-term glucose control. In addition, the role of $\mathrm{HbAlc}$ was further broadened as the guidelines from the American Diabetes Association ${ }^{2)}$ and the World Health Organization ${ }^{3)}$ introduced $\mathrm{HbAlc}$ for the diagnosis of DM in 2009.

There has been increasing interest in nontraditional glycemic markers as alternatives to $\mathrm{HbAlc}^{4,5}$. Because of the situations that can be reduced the validity of $\mathrm{HbAlc}$ test, it is important to interpret $\mathrm{HbAlc}$ values in various conditions. This article will review the limitations of $\mathrm{HbAlc}$ measurement and the current knowledge about alternative glycemic biomarkers, including fructosamine, glycated albumin (GA), and 1,5-anhydroglucitol (1,5-AG).

\section{Limitations of HbA1c}

$\mathrm{HbAlc}$ are influenced by red blood cells (RBC) survival. Because the average lifespan of RBC is 120 days, $\mathrm{HbAlc}$ reflects mean glucose levels over the preceding two to three months. Falsely elevated $\mathrm{HbAlc}$ in relation to a mean blood glucose concentrations can be achieved when RBC turnover is decreased, resulting in a disproportionate number of older RBC. This problem can occur in patients with iron, vitamin B12, or folate deficiency anemia. Inversely, increased RBC turnover leads to a greater proportion of younger RBC and falsely lowed $\mathrm{HbAlc}$ values, such 
as in conditions with acute and chronic blood loss, hemolysis or pregnancy, anemia and patients treated for iron, vitamin B12, or folate deficiency, and treated with erythropoietin ${ }^{6-8)}$. HbAlc values may be falsely high or low in those with end-stage renal disease ${ }^{9)}$.

HbAlc cannot be used as a glycemic marker in neonatal DM. During the perinatal period, fetal hemoglobin $(\mathrm{HbF})$ is the main component of hemoglobin and less than $10 \%$ is hemoglobin A. HbAlc values typically are low in relation to hyperglycemia in neonatal diabetes. HbAlc is influenced by changes according to age in $\mathrm{HbF}$, and does not precisely reflect glycemic control in neonate $^{10,11)}$

In addition, HbAlc levels are no accurate in reflecting shortterm glycemic changes. While glycemic control changes rapidly, $\mathrm{HbA1c}$ changes gradually. As a result, measuring $\mathrm{HbAlc}$ to evaluate responses to glucose-lowering treatment in DM patients may be useful after twelve weeks ${ }^{12}$. In patients with fulminant type 1 DM (in which hyperglycemia rapidly occurs), HbAlc may not be a reliable indicator due to its normal or only slightly elevated levels ${ }^{13)}$.

Mean $\mathrm{HbAlc}$ values are associated with the development and progression of diabetic complications ${ }^{14-16)}$. Several studies have noted the relationship between postprandial hyperglycemia and cardiovascular disease ${ }^{15)}$. Better control of glycemic variability is one of the most important ways to prevent cardiovascular disease in diabetes. HbAlc is a measure that mainly reflects average serum glucose concentration, but it does not separately reflect postprandial hyperglycemia and fasting hyperglycemia ${ }^{15,16)}$.

\section{Alternative biomarkers}

There are several alternative biomarkers to $\mathrm{HbAlc}$ in use today, including fructosamine, GA, 1,5-AG, and continuous glucose monitoring, described below.

\section{Fructosamine}

Fructosamine is a ketoamine formed from the binding of fructose to total serum protein, mostly albumin, through glycosylation ${ }^{17)}$. The term fructosamine includes all glycated proteins. Fructosamine assays are cheaper and easier to perform than HbAlc assays. Serum fructosamine values reflect mean blood glucose concentrations over the previous two to three weeks, which can be used clinically as markers of recent changes in glycemic control. When used in combination with other measures, it may play a role in identifying fluctuating glucose levels in DM patients with stable HbAlc. There is a good correlation between $\mathrm{HbAlc}$ values and serum fructosamine ${ }^{18,19)}$.

There are also several limitations to the use of serum fructosamine measurements. The higher within-subject variation for fructosamine than that for HbAlc means that frequent measurements must be conducted ${ }^{20)}$. Serum fructosamine values must be adjusted if the serum albumin concentration is abnormal ${ }^{21)}$. Falsely low levels in relation to mean blood glucose levels will occur with rapid albumin turnover, such as in nephrotic syndrome, severe liver disease, or protein-losing enteropathy. The level of fructosamine in young children is lower than that in adults, which is also partly due to their lower serum protein concentration $^{22)}$.

\section{Glycated albumin}

GA is the proportion of the serum GA to the total albumin. GA is similar to serum fructosamine, except that is not affected by serum albumin levels ${ }^{23}$. The level of GA is approximately three times higher than that of $\mathrm{HbAlc}$. Since the half-life of albumin is shorter than that of RBC, GA reflects a shorter duration, two to three weeks, of glycemic control, than that of $\mathrm{HbAlc}^{24)}$. GA and fructosamine are strongly associated with HbAlc and fasting glucose $\mathrm{e}^{25-27)}$.

\section{1) Clinical usefulness of GA}

GA has several advantages for monitoring for glucose control. The first is that it is not influenced by abnormal RBC lifespan or variant hemoglobin. GA is a particularly useful indicator of glycemic control in hematologic disorders, such as in anemia, hemorrhage, renal anemia, pregnancy, liver cirrhosis, and neonatal DM. The second advantage is that GA may be quite useful for conditions in which glycemia improves rapidly, or in which glycemia deteriorates rapidly, such as in fulminant type I DM. GA will provide a more accurate assessment of recent glycemia. Finally, when compared with $\mathrm{HbAlc}$ values, GA values have more correlation with postprandial glucose levels and glucose excursions ${ }^{28,29)}$. Because the glycation speed of GA is ten times faster than HbAlc, GA is likely to reflect variations in blood glucose and postprandial hyperglycemia in combination with $\mathrm{HbAlc}$ and its value ${ }^{30)}$. It has been reported that GA is related to daily glucose fluctuation ${ }^{20)}$.

\section{2) Limitations of GA}

GA has abnormal values in diseases that result in abnormal albumin metabolism. The rise of albumin metabolism leads to low GA levels in diseases including nephrotic syndrome, hyperthyroidism, glucocorticoid administration, Cushing's syndrome, and in neonates ${ }^{10,31-33)}$. Whereas albumin metabolism decreases, high GA levels are seen in diseases such as liver cirrhosis and hypothyroidism ${ }^{34)}$.

Unlike HbAlc, GA is inversely influenced by obesity. GA tends to be lower in obese subjects with a high percentage of body fat mass ${ }^{35)}$. In addition, GA levels in infants significantly increase with age $\mathrm{e}^{36)}$. The serum glucose levels of infants are lower than that of adults, and higher albumin metabolism is associated with lower GA levels.

\section{1,5-anhydroglucitol}

The 1-deoxy form of glucose known as 1,5-AG is a naturally occurring dietary polyol. During euglycemia, serum 1,5-AG concentrations are maintained at a constant steady state due 
to renal tubular reabsorption of all of the serum 1,5-AG. The normal serum concentration of $1,5-\mathrm{AG}$ has been reported to be $12-40 \mu \mathrm{g} / \mathrm{mL}^{37)}$. Serum $1,5-\mathrm{AG}$ competes with very high levels of glucose for reabsorption into the kidney. Within 24 hours of a rise in serum glucose to $>180 \mathrm{mg} / \mathrm{dL}$, serum circulating 1,5AG falls as urinary losses increase ${ }^{38,39)}$. Lower serum 1,5-AG levels reflect high circulating glucose and the occurrence of glycosuria over the past 1 to 2 weeks ${ }^{40,41)}$. Measurement of serum 1,5-AG may reflect postprandial glycemic excursion rather than $\mathrm{HbAl} \mathrm{c}^{42-44)}$. While 1,5-AG may have clinical implications for the evaluation and treatment of glycemic excursions in type 1 diabetes ${ }^{45}$, this test is affected by alteration in renal hemodynamics.

\section{Continuous glucose monitoring}

Although the use of continuous glucose monitoring can accurately evaluate the glycemic variability of within-day and between-day, the current continuous glucose monitoring systems are expensive without national health insurance coverage and are not easily available in clinical practice. Furthermore, they are relatively inaccurate in the lower glucose range, and should be used in conjunction with self-monitoring of blood glucose ${ }^{46)}$.

\section{Conclusions}

The growing attention to nontraditional glycemic biomarkers is attributable to the limitations of the HbAlc assay ${ }^{47-49)}$. It is important to recognize the conditions in which $\mathrm{HbAlc}$ levels may be difficult to interpret. Use of these alternative markers can be more helpful in the management of diabetes as complement standard measures. There are generally good correlations of $\mathrm{HbAlc}$ with serum fructosamine and GA. Fructosamine and GA have been proposed to be useful tools for monitoring shortterm glycemic control. These biomarkers not only reflect well glycemic control in hematologic disorder, but also represent postprandial glucose fluctuation. Serum 1,5-AG may be useful for estimating within-day glycemic excursion. Nevertheless, there are no definitive guidelines for using alternative biomarkers as adjuncts to standard markers of glycemia, such as $\mathrm{HbAlc}$, fasting glucose, or self-monitoring blood glucose measures ${ }^{49)}$. Long-term prospective studies are still lacking. Further larger cohort studies are warranted to determine whether alternative biomarkers have potential utility for early diagnosis, management of diabetes, and prevention of diabetic complications.

\section{Conflict of interest}

No potential conflict of interest relevant to this article was reported.

\section{References}

1. Goldstein DE, Little RR, Lorenz RA, Malone JI, Nathan D, Peterson CM. Tests of glycemia in diabetes. Diabetes Care 1995;18:896-909.

2. International Expert Committee. International Expert Committee report on the role of the $\mathrm{AlC}$ assay in the diagnosis of diabetes. Diabetes Care 2009;32:1327-34.

3. Use of glycated haemoglobin (HbAlc) in the diagnosis of diabetes mellitus: abbreviated report of a WHO Consultation. Geneva: World Health Organization, 2011.

4. Radin MS. Pitfalls in hemoglobin Alc measurement: when results may be misleading. J Gen Intern Med 2014;29:38894.

5. Parrinello CM, Selvin E. Beyond HbAlc and glucose: the role of nontraditional glycemic markers in diabetes diagnosis, prognosis, and management. Curr Diab Rep 2014;14:548.

6. National Glycohemoglobin Standardization Program (NGSP). Factors that Interfere with $\mathrm{HbA1c}$ test results [Internet]. NGSP; c2011 [cited 2015 May 20]. Available from: http://www.ngsp.org/factors.asp.

7. Polgreen PM, Putz D, Stapleton JT. Inaccurate glycosylated hemoglobin A1C measurements in human immunodeficiency virus-positive patients with diabetes mellitus. Clin Infect Dis 2003;37:e53-6.

8. Brown JN, Kemp DW, Brice KR. Class effect of erythropoietin therapy on hemoglobin $\mathrm{A}(1 \mathrm{c})$ in a patient with diabetes mellitus and chronic kidney disease not undergoing hemodialysis. Pharmacotherapy 2009;29:468-72.

9. Ly J, Marticorena R, Donnelly S. Red blood cell survival in chronic renal failure. Am J Kidney Dis 2004;44:715-9.

10. Suzuki S, Koga M, Niizeki N, Furuya A, Matsuo K, Tanahashi Y, et al. Evaluation of glycated hemoglobin and fetal hemoglobin-adjusted HbAlc measurements in infants. Pediatr Diabetes 2013;14:267-72.

11. Suzuki S, Koga M, Amamiya S, Nakao A, Wada K, Okuhara $\mathrm{K}$, et al. Glycated albumin but not $\mathrm{HbAlc}$ reflects glycaemic control in patients with neonatal diabetes mellitus. Diabetologia 2011;54:2247-53.

12. Koga M, Murai J, Saito H, Kasayama S. Prediction of nearfuture glycated hemoglobin levels using glycated albumin levels before and after treatment for diabetes. J Diabetes Investig 2011;2:304-9.

13. Imagawa A, Hanafusa T, Miyagawa J, Matsuzawa Y. A novel subtype of type 1 diabetes mellitus characterized by a rapid onset and an absence of diabetes-related antibodies. Osaka IDDM Study Group. N Engl J Med 2000;342:301-7.

14. The effect of intensive treatment of diabetes on the development and progression of long-term complications in insulin-dependent diabetes mellitus. The Diabetes Control and Complications Trial Research Group. N Engl J Med 1993;329:977-86.

15. Wang PH, Lau J, Chalmers TC. Meta-analysis of effects of intensive blood-glucose control on late complications of type I diabetes. Lancet 1993;341:1306-9. 
16. Reichard P, Nilsson BY, Rosenqvist U. The effect of longterm intensified insulin treatment on the development of microvascular complications of diabetes mellitus. N Engl J Med 1993;329:304-9.

17. Mosca A, Carenini A, Zoppi F, Carpinelli A, Banfi G, Ceriotti F, et al. Plasma protein glycation as measured by fructosamine assay. Clin Chem 1987;33:1141-6.

18. Pandya HC, Livingstone S, Colgan ME, Percy-Robb IW, Frier BM. Serum fructosamine as an index of glycaemia: comparison with glycated haemoglobin in diabetic and non-diabetic individuals. Pract Diabetes Int 1987;4:126-8.

19. Narbonne H, Renacco E, Pradel V, Portugal H, Vialettes B. Can fructosamine be a surrogate for $\mathrm{HbA}(1 \mathrm{c})$ in evaluating the achievement of therapeutic goals in diabetes? Diabetes Metab 2001;27(5 Pt 1):598-603.

20. Matsumoto H, Murase-Mishiba Y, Yamamoto N, SugitatsuNakatsukasa S, Shibasaki S, Sano H, et al. Glycated albumin to glycated hemoglobin ratio is a sensitive indicator of blood glucose variability in patients with fulminant type 1 diabetes. Intern Med 2012;51:1315-21.

21. Howey JE, Browning MC, Fraser CG. Assay of serum fructosamine that minimizes standardization and matrix problems: use to assess components of biological variation. Clin Chem 1987;33(2 Pt 1):269-72.

22. Miyazaki A, Kohzuma T, Kasayama S, Koga M. Classification of variant forms of haemoglobin according to the ratio of glycated haemoglobin to glycated albumin. Ann Clin Biochem 2012;49(Pt 5):441-4.

23. Kim D, Kim KJ, Huh JH, Lee BW, Kang ES, Cha BS, et al. The ratio of glycated albumin to glycated haemoglobin correlates with insulin secretory function. Clin Endocrinol (Oxf) 2012;77:679-83

24. Koga M, Hashimoto K, Murai J, Saito H, Mukai M, Ikegame $\mathrm{K}$, et al. Usefulness of glycated albumin as an indicator of glycemic control status in patients with hemolytic anemia. Clin Chim Acta 2011;412:253-7.

25. Juraschek SP, Steffes MW, Selvin E. Associations of alternative markers of glycemia with hemoglobin A(1c) and fasting glucose. Clin Chem 2012;58:1648-55.

26. Lee JW, Kim HJ, Kwon YS, Jun YH, Kim SK, Choi JW, et al. Serum glycated albumin as a new glycemic marker in pediatric diabetes. Ann Pediatr Endocrinol Metab 2013;18:208-13.

27. Shin YS, Park J, Kang DS, Yu J. Significance of the measurement of serum fructosamine in the management of childhood diabetes. Int J Pediatr Endocrinol 2013;2013 (Suppl 1):P36.

28. Koga M, Murai J, Morita S, Saito H, Kasayama S. Comparison of annual variability in $\mathrm{HbAlc}$ and glycated albumin in patients with type 1 vs. type 2 diabetes mellitus. J Diabetes Complications 2013;27:211-3.

29. Hirsch IB, Brownlee M. Beyond hemoglobin A1c--need for additional markers of risk for diabetic microvascular complications. JAMA 2010;303:2291-2.

30. Chon S, Lee YJ, Fraterrigo G, Pozzilli P, Choi MC, Kwon
MK, et al. Evaluation of glycemic variability in well-controlled type 2 diabetes mellitus. Diabetes Technol Ther 2013;15:455-60

31. Koga M, Murai J, Saito H, Otsuki M, Kasayama S. Evaluation of the glycated albumin/HbAlc ratio by stage of diabetic nephropathy. Diabetol Int 2011;2:141-5.

32. Koga M, Murai J, Saito H, Matsumoto S, Kasayama S. Effects of thyroid hormone on serum glycated albumin levels: study on non-diabetic subjects. Diabetes Res Clin Pract 2009;84:163-7.

33. Suzuki S, Koga M, Takahashi H, Matsuo K, Tanahashi Y, Azuma H. Glycated albumin in patients with neonatal diabetes mellitus is apparently low in relation to glycemia compared with that in patients with type 1 diabetes mellitus. Horm Res Paediatr 2012;77:273-6.

34. Koga M. Glycated albumin: clinical usefulness. Clin Chim Acta 2014;433:96-104.

35. Koga M, Matsumoto S, Saito H, Kasayama S. Body mass index negatively influences glycated albumin, but not glycated hemoglobin, in diabetic patients. Endocr J 2006;53:387-91

36. Suzuki S, Koga M, Niizeki N, Furuya A, Takahashi H, Matsuo K, et al. Glycated albumin is lower in infants than in adults and correlated with both age and serum albumin. Pediatr Diabetes 2013;14:25-30.

37. Yamanouchi T, Akanuma Y. Serum 1,5-anhydroglucitol (1,5 AG): new clinical marker for glycemic control. Diabetes Res Clin Pract 1994;24 Suppl:S261-8.

38. Buse JB, Freeman JL, Edelman SV, Jovanovic L, McGill JB. Serum 1,5-anhydroglucitol (GlycoMark ): a short-term glycemic marker. Diabetes Technol Ther 2003;5:355-63.

39. Dungan KM. 1,5-anhydroglucitol (GlycoMark) as a marker of short-term glycemic control and glycemic excursions. Expert Rev Mol Diagn 2008;8:9-19.

40. Yamanouchi T, Minoda S, Yabuuchi M, Akanuma Y, Akanuma $\mathrm{H}$, Miyashita $\mathrm{H}$, et al. Plasma 1,5-anhydro-D-glucitol as new clinical marker of glycemic control in NIDDM patients. Diabetes 1989;38:723-9.

41. Stettler C, Stahl M, Allemann S, Diem P, Schmidlin K, Zwahlen M, et al. Association of 1,5-anhydroglucitol and 2 -h postprandial blood glucose in type 2 diabetic patients. Diabetes Care 2008;31:1534-5.

42. Kishimoto M, Yamasaki Y, Kubota M, Arai K, Morishima T, Kawamori R, et al. 1,5-Anhydro-D-glucitol evaluates daily glycemic excursions in well-controlled NIDDM. Diabetes Care 1995; 18:1156-9.

43. McGill JB, Cole TG, Nowatzke W, Houghton S, Ammirati EB, Gautille T, et al. Circulating 1,5-anhydroglucitol levels in adult patients with diabetes reflect longitudinal changes of glycemia: a U.S. trial of the GlycoMark assay. Diabetes Care 2004;27:1859-65.

44. Dungan KM, Buse JB, Largay J, Kelly MM, Button EA, Kato S, et al. 1,5-anhydroglucitol and postprandial hyperglycemia as measured by continuous glucose monitoring system in moderately controlled patients with diabetes. Diabetes Care 
2006;29:1214-9.

45. Seok H, Huh JH, Kim HM, Lee BW, Kang ES, Lee HC, et al. 1,5-anhydroglucitol as a useful marker for assessing shortterm glycemic excursions in type 1 diabetes. Diabetes Metab J 2015;39:164-70.

46. Chiang JL, Kirkman MS, Laffel LM, Peters AL; Type 1 Diabetes Sourcebook Authors. Type 1 diabetes through the life span: a position statement of the American Diabetes Association. Diabetes Care 2014;37:2034-54.
47. Juraschek SP, Steffes MW, Miller ER 3rd, Selvin E. Alternative markers of hyperglycemia and risk of diabetes. Diabetes Care 2012;35:2265-70.

48. Rondeau P, Bourdon E. The glycation of albumin: structural and functional impacts. Biochimie 2011;93:645-58.

49. Goldstein DE, Little RR, Lorenz RA, Malone JI, Nathan D, Peterson CM, et al. Tests of glycemia in diabetes. Diabetes Care 2004;27:1761-73. 